\title{
ВНЕСОК ВАСИЛІЯНСЬКИХ УЧЕНИХ В УКРАЇНСЬКУ ІСТОРІОГРАФІЮ В КОНТЕКСТІ НАУКОВОЇ ПЕРІОДИКИ У ДРУГІЙ ПОЛОВИНІ ХХ ст.
}

\author{
Мар'ян Лозинський \\ Львівський наиіональний університет імені Івана Франка \\ вул. Генерала Чупринки, 49, 79044, Львів, Україна \\ e-mail:Lozmaryk@gmail.com \\ https://orcid.org/0000-0002-5006-3291
}

Подано оцінку видавничої діяльності знаменитих отців-письменників Василіянського Чину. Йдеться про Платоніда Філяса, Сотера Ортинського, Андрея Шептицького. Науково-богословські праці цих священників збагатили релігійно-національну спадщину Української держави у XX столітті як в Україні, так і за їі межами. Стаття зацікавить тих, хто досліджує наукову церковну періодику.

Ключові слова: науково-богословські праці, священники, «Нива», «Богословія», «Записки ЧСВВ».

Постановка проблеми. Василіянська історіографія другої половини XX ст. має історичне відображення та добре започатковану джерельну базу, яку розпочали зреформовані Добромильською реформою отці василіяни. 3 того часу - започатковані василіянські наукові дослідження та публікації, які пов’язані із такими постатями Василіянського Чину, як Платонід Філяс, Сотер Ортинський, Мелетій Лончина, Климентій Сарницький, Андрей Шептицький та ін.

Методологічна основа дослідження. В процесі написання статті використано такі методи: аналізу (виділено праці отців василіян з ділянки історіографії), синтезу (поєднано ці праці за тією самою тематикою), контент-аналізу (розглянуто зміст наукових видань, де публікувалися названі праці), порівняння (вказано на їхні спільні риси), узагальнення (узагальнено значення праць з історіографії для вивчення періодики) та ін.

Виклад основного матеріалу дослідження. 3-поміж наукових світил УГКЦ виокремимо спершу о. Теодосія Тита Галущинського (1880-1952), який проклав живий місток між довоєнною василіянською історіографією, що розвивалася в Галичині і на Закарпатті у 20-30 роках XX ст., та науковим осередком, який створили василіянські науковці в Римі після Другої світової війни. Біографи о. Т. Галущинського вказують на його інтенсивну наукову діяльність, зокрема: організаційну, педагогічну й дослідницьку. Він був одним з ініціаторів створення і першим головою Богословського Наукового Товариства у Львові (1923-1926), а в 1931 році заснував

(c) Лозинський М., 2020 
науково-релігійний щоквартальник «Добрий пастир» і був його першим редактором. У 1948 році відродив видання «Записок ЧСВВ» у Римі і відредагував 1-й випуск 2-ї секції (Analecta OSBM. - Romae, 1949). Автори публікацій про Т. Галущинського досліджують його науковий доробок за такими чотирма циклами:

Перший - праці з історії Святого Письма Старого й Нового Завітів.

Другий - історіографічні дослідження.

Третій - публікації з догматичної, морально-аскетичної, філософсько-соціологічної і педагогічної проблематики.

Четвертий - рецензії на українські та іноземні історико-церковні та біблійно-історичні видання.

Свої наукові праці він публікував у вітчизняних та закордонних виданнях, якот: «Нива», «Богословія», «Записки ЧСВВ», «Добрий Пастир», «Нова Зоря», «Bonifatius Korrespondent», «Ex Oriente», «Irenikon», «La Croix», «L'Osservatore Romano», «Catholica Unio» та ін. Важливіші $з$ його журнальних публікацій вийшли окремими виданнями. Після війни переклав українською мовою і видав тексти Святого Письма Нового Завіту (Свангелія і Діяння апостолів). За визначні наукові досягнення о. Т. Галущинського у 1952 році обрали дійсним членом Наукового Товариства ім. Т. Шевченка.

Найбільшими історіографічними працями цього автора дослідники вважають видання документів Папи Римського Іннокентія III (1198-1216), які стосуються християнського Сходу, в тому числі Русі. Іншими важливими працями о. Т. Галущинського, на думку дослідників, $є$ підготовані до друку зібрання документів римських пап Іннокентія IV (1243-1254) та Олександра IV (1254-1261), які вийшли у світ у доопрацюванні його учня Мелетія Войнара ${ }^{1}$. Оцінюючи першу із зазначених праць о. Т. Галущинського, о. I. Назарко назвав її «імпозантним томом», адже це перше «критичне видання письма Інокентія III дотично східних справ за час цілого його понтифікату», що припав на драматичний період в історії Константинополя та залежних від нього Східних Церков після 1204 року².

Іншим василіянським істориком 2-ї половини XX ст., який своїми дослідженнями і публікаціями джерел сягнув європейського рівня, був о. Атанасій Григорій Великий (1918-1982). 3 огляду на це, його науковому доробкові в українській та іноземній історіографії присвячено найбільше статей, розвідок і рецензій.

Варто зазначити, що Атанасій Григорій Великий - один з тих василіянських учених, кому діаспорна і вітчизняна історіографія вділила найбільше уваги. Про о. А. Великого та його науковий доробок писали його духовні співбрати по Чину,

1 «Acta Innocentii IV» (1243-1254). (1962), E Regestis Vaticanis aliisque Fontibus collegerunt notisque adornarunt Theodosius T. Haluščynskyj [...]et Meletius Wojnar OSBM, Pontificia Commissio ad Redigendum Codicem Juris canonici orientalis: Fontes, Ser. III, Vol. 4, t. 1. Romae, XLIV+226 p.

2 Назарко, I. (1972), «Отець д-р Теодосій Тит Галущинський ЧСВВ», за ред. Михайла Островерхи, Бучач і Бучаччина. Історично-мемуарний збірник, НТШ, Український архів, т. XXVII. Ню Йорк, Лондон, Париж, Сидней, Торонто, с. 116-119. 
зокрема, І. Патрило М. Ваврик ${ }^{4}$ а також світські науковці: О. Пріцак ${ }^{5}$, В. Ленцик П. Шкраб'юк', С. Плохій, О. Ясь та ін. Про цього історика-василіянина йдеться і в загальних оглядах української церковної історіографії. Бібліографію його наукових праць уклав Г. Кінах ${ }^{8}$. Усі, хто писав про Атанасія Григорія Великого, передусім відзначають його видатний внесок в українську церковну археографію. Зокрема, він зібрав, упорядкував, опрацював (проанотував з численними примітками і науковим апаратом) чимало документів з римських, головно - ватиканських архівів, що стосуються історії Української Церкви та українсько-ватиканських політичних і церковних взаємин XI-XIX ст.; започаткував і підготував видання 12-ти серій документальних публікацій.

Усі ці розлогі збірки документів числом 55 книг Атанасій Григорій Великий видав у серії окремих томів 3-ї секції «Записок ЧСВВ» / «Analecta OSBM», яку він сам заснував та був її незмінним науковим редактором ${ }^{9}$. Наголосимо, що велику допомогу у виданні цього монументального зібрання о. Атанасію Великому надали його колеги-науковці, зокрема Іриней Назарко, Михайло Ваврик, Ісидор Патрило, Порфирій Підручний.

Даючи загальну оцінку археографічним працям Атанасія Великого, дослідники одностайно засвідчують високий рівень їхнього науково-методологічного опрацювання і видання. Зокрема, академік Омелян Пріцак стверджував, що «принципи, опрацьовані о. доктором А. Великим, ... відповідали станові археографічної науки і були великим кроком уперед... Вони дали українській науці добрі плоди» ${ }^{10}$.

До плеяди визначних василіянських істориків 2-ї половини XX ст. належить і Михайло Мирослав Ваврик (1908-1984), автобіографія якого була опублікована у науковому періодичному виданні «Записки ЧСВВ» (Сер. 2, Сек. 2. Рим, 1985. Т. 12. Вип. 1/4. С. 165-170). Його постать і науковий доробок в царині історичних студій стали об'єктом висвітлення в низці спеціальних досліджень. Зокрема, розвідки про нього написали й опублікували його співбрати по Чину - відомі історики А. Пекар ${ }^{11}$,

3 Патрило, І. (1985), «Життя і творчість о. Атанасія Великого, ЧСВВ», Записки ЧСВВ, сер. 2, сек. 2, т. 12. Рим, с. 3-57

4 Ваврик, М. (1985), «Провідні ідеї праць о. А. Великого в його студіях української церковної історії», Записки ЧСВВ, сер. 2, сек. 2, т. 12. Рим, с. 7-84.

5 Пріцак, О.(1985), «Отець Атанасій Великий, ЧСВВ - археограф», Записки ЧСВВ, сер. 2, сек. 2, т. 12. Рим, с. $58-68$.

6 Ленцик, В. (1985), «Отець Атанасій Г. Великий - як історик Української Церкви», Записки ЧСВВ сер. 2 , сек. 2 , т. 12 . Рим, с. $69-76$;

7 Шкраб'юк, П.(2005), Монаший Чин отиів Василіян унаціональномужстті Украйни: Монографія, Львів, ВВП «Місіонер», с. 259-275.

8 Кінах, Г. (1974), «Бібліографія о. Атанасія Г. Великого, ЧСВВ - ініціатора і співробітника другої серії «Записок ЧСВВ», Записки ЧСВВ, сер. 2, сек. 2, т. 9. Рим, с. 303-324.

9 «Acta S. Congregationis de Propaganda Fide Ecclesiam Catholicam Ucrainae et Bielarusjae spectantia», (1953), Collegit A. G. Welykyj, Analecta OSBM, ser.2, sec.3, vol.1. Romae, XVI+368 p.

10 Пріцак, О. (1985), «Отець Атанасій Великий, ЧСВВ - археограф», Записки ЧСВВ, сер. 2, сек. 2, т. 12. Рим, с. 65.

${ }^{11}$ Пекар, А. (1985), «Отець М. Ваврик, ЧСВВ - як історик Василіянського Чину», Записки ЧСВВ. сер. 2 , сек. 2 , т. 12, вип. 1/4. Рим, с. 171-187. 
М. Войнар ${ }^{12}$, а також світський дослідник В. Ленцик. У науковій спадщині М. Ваврика вони виділяють такі цикли:

1. Василіанська бібліографія;

2. Архівні пошуки;

3. Літургійні розвідки;

4. Біографічні нариси;

5. Історіографічні дослідження;

6. Енциклопедичні статті-гасла.

У рамках нашої статті найбільший інтерес становлять бібліографічні та історіографічні праці М. Ваврика та їхня оцінка з боку дослідників. Отож, на їхню думку, М. Ваврик - це передусім бібліограф та історик Василіянського Чину. Він є автором двох фундаментальних збірників: «Бібліографічний огляд історії Василіянського Чина за 1935-1950 рр.» («Записки ЧСВВ». Сер. 2, Сек. 2. Рим, 1960. Т.3. Вип.3/4. С. 237-276), «Бібліографічний огляд історії Василіянського Чина за 1950-1970 рр.» («Записки ЧСВВ». Сер. 2, Сек. 2. Рим, 1971. Т. 7. Вип. 1/4. С. 334-424).

У цих працях М. Ваврик зібрав й описав майже всі публікації, присвячені різним аспектам василіянської історії, що були написані й оприлюднені до 1970 року. До кожної позиції він подавав її короткий зміст, зробив суттєві доповнення, виправляв неточності, допущені автором, а наприкінці давав стислу оцінку анотованої статті, монографії чи розвідки ${ }^{13}$.

Науковці наголошують на великому доробку М. Ваврика як архівіста й дослідника рукописних пам'яток, які він відшукав у різних архівах і бібліотеках. Тут він застосував спеціальні знання, які здобув, навчаючись на курсах архівістики й бібліотекознавства при Ватикані та в Папському Східному Інституті.

У першій із цих публікацій М. Ваврик подав скорочені виписки з рукописної «Хроніки» Лаврівського монастиря, що біля Старого Самбора, які він зробив у 1924-1927 рр., коли навчався в тамтешній школі. У цьому та інших безцінних описах М. Ваврик врятував від знищення значну частину давньої Лаврівської хроніки, а також «важливіші грамоти від цілковитого знищення, зберігши їх хоч би в скороченому вигляді для наступних поколінь» ${ }^{14}$.

Для повноти образу М. Ваврика як ученого й дослідника потрібно ще додати, - i в публікаціях про нього це зазначено, - що він був активним співробітником словникової частини «Енциклопедії Українознавства» (ЕУ-2), для якої написав і відредагував переважну більшість гасел з історії українського монашества.

Поряд із Т. Галущинським, А. Великим, М. Вавриком спеціальних розвідок про життя, служіння і наукову діяльність удостоїлися також інші історики-василіяни. Зокрема, досліджено постать Іринея Івана Назарка (1905-1976) - ієромонаха ЧСВВ, релігійно-суспільного діяча, глибокого дослідника в царині української політично-церковної історії.

Щодо його наукового доробку, то дослідники виділяють дві його головні історико-наукові праці: монографію «Святий Володимир Великий - володар і хрес-

12 Войнар, М. (1985), «Отець Михайло Ваврик, ЧСВВ - педагог», Записки ЧСВВ, сер. 2, сек. 2. т. 12, вип. 1/4, Рим, с. 195-199.

13 Пекар, А. (1985), «Отець М. Ваврик, ЧСВВ - як історик Василіянського Чину», Записки ЧСВВ, сер. 2 , сек. 2 , т. 12 , вип. $1 / 4$. Рим, с. 174.

${ }^{14}$ Там само, с. 176. 
титель Руси-України (960-1015)» ${ }^{15}$ (Рим, 1954) і книгу нарисів «Київські і Галицькі митрополити (1590-1960)» (Рим, 1962)

Наголошено, що у своїх дослідженнях І. Назарко - чи не єдиний серед істориків-василіян вдало поєднував історично-церковний аспект із суспільно-політичним. Його монографія про св. Володимира слугує цьому яскравим підтвердженням. Свідчать про це і його новаторські розвідки, зокрема, статті «Блаженний папа Інокентій XI і Україна», «Знаменне письмо козаків до папи римського», «Братства та їх роля в історії Української Церкви», «Лист єпископа Суші до гетьмана І. Виговського», «Роля козаків у протитурецькій кампанії під Віднем 1683 р. в насвітленні ватиканських документів», «Призабутий попередник М. Шашкевича - о. Юліан Добриловський», «Акція митрополита А. Шептицького напередодні рішення Ради Амбасадорів 1923 р.», які були опубліковані на сторінках наукових періодичних видань української діаспори в Свропі та Канаді.

У цих та інших публікаціях цей василіянський історик показав генетичну спорідненість української церковної історії з політичною та культурною історією України. У цьому весь Іриней Назарко - священник-василіянин, релігійно-суспільний діяч і вчений.

Серед провідних істориків-василіян важливе місце посідає Ісидор Іван Патрило (1919-2008). Його юність і становлення, як і більшості василіянських інтелектуалів повоєнного періоду, припадає на 30-40-і роки ХХ ст.

Першим серйозним дебютом о. I. Патрила як науковця-дослідника була його латиномовна докторська дисертація «Архієпископи-митрополити Києво-Галицькі», що вийшла друком у Римі 1962 року ${ }^{17}$ й одразу привернула увагу наукового світу.

Науковою новизною дисертації є те, що це, по суті, перша в українській церковній історіографії праця, в якій розглянуто правове становище і владу києво-галицьких митрополитів від початку організованого існування ієрархічних структур Української Церкви до Берестейської унії (Ч. 1) і далі аж до відновлення самостійної Галицької митрополії 1807 р. (Ч. 2).

Зазначимо, що високо оцінили вітчизняні дослідники тритомну працю І. Патрила «Джерела і бібліографія історії Української Церкви», що вийшла в Римі в 1975/1988/1994 роках.

Зокрема, відомий сучасний український історик Церкви Василь Ульяновський відгукнувся на це фундаментальне видання спеціальною статтею. Він називав твір I. Патрила «титанічною працею, яка подає до рук кожного зацікавленого в пізнанні історії церкви на Україні усю найважливішу (особливо стосовно зарубіжних видань) інформацію... Це необхідний компендіум бібліографічної інформації з історії церкви на Україні, який має бути відомий не лише серйозним дослідникам, але й початківцям та аматорам, зокрема журналістам» ${ }^{18}$.

${ }^{15}$ Назарко, I. (1954), «Святий Володимир Великий - володар і хреститель Руси-України (9601015)», Записки ЧСВВ, сер. 2, сек. 1: Праці, т. IV. Рим, XXXII+228 с.

${ }^{16}$ Назарко, I.(1962), «Київські і Галицькі митрополити. Біографічні нариси (1590-1960)». Записки ЧСВB, сер. 2, сек. 1: Праці, т. XIII. Рим, XVIII+272 с.

${ }^{17}$ Patrylo, I. (1962), «Archiepiscopi-Metropolitani Kievo-Halicienses», Analecta OSBM, ser. 2, sec. 1: Opera, vol. XVII. Romae, XVI+142.

18 Ульяновський, В. (1994), «Збирач дорогоцінного каміння: Унікальна праця отця I. Патрила», «Старожитності», № 7/8 (66/67), с. 7-8. 
Цінним у статті В. Ульяновського є також те, що він подав детальну інформацію про самого Ісидора Патрила та про його найважливіші праці з історії церкви $\mathrm{i}$ релігійно-церковних відносин в Україні ${ }^{19}$.

Завершуючи розгляд українських публікацій про представників василіянської історіографії 2-ї половини XX ст., варто згадати й про науково-інформаційні видання, в яких подано біографії низки істориків-василіян і загальну оцінку внеску кожного 3 них в українську історичну науку. Це передусім видання Інституту історії НАН України «Українські історики ХХ століття: Бібліографічний довідник».

Розгорнуті статті-гасла про декого з василіянських істориків новітнього часу опублікував львівський дослідник Іван Паславський в другому томі «Енциклопедії НТШ». Він, зокрема, є автором гасел про М. Ваврика, А. Великого, М. Войнара і Т. Галущинського. Цінним аспектом його публікацій є те, що, окрім біографічних даних, він подав наукову бібліографію основних праць цих істориків та літературу про кожного з них.

Стислий, але суттєвий аналіз василіянської історіографії, в тому числі повоєнної, зробив відомий дослідник національно-культурної місії отців василіян д-р Петро Шкраб'юк. Він, зокрема, здійснив загальний огляд науково-дослідницьких досягнень таких істориків-василіян, як Севастіан Сабол, Мелетій Войнар, Іриней Назарко, Мелетій Соловій, Ісидор Патрило, Михайло Ваврик, Порфирій Підручний та ін. Проте найбільше уваги П. Шкраб'юк приділив о. А. Великому, який, за його оцінкою, був «великим не так через своє прізвище, як завдяки своїй колосальній науковій праці» ${ }^{20}$.

Висновки. Аналіз українських наукових публікацій про василіянську історіографію 2-ої половини XX ст. дає підстави для таких висновків:

1. Українську історіографію у доробку істориків-василіян потрібно досліджувати у двох періодах: діаспорному і вітчизняному.

2. Діаспорну історіографію поділяють на церковну і світську.

3. Для церковної наукової історіографії окресленої теми характерними є виважений підхід й одностайно позитивна оцінка. Наголосимо, що діаспорна церковна історіографія, за всієї своєї науковості, дещо однобока, суб'єктивна, особливо стосовно висвітлення доробку братів по конфесії чи монашому служінню. Однак світський дослідник, вивчаючи історію Української Церкви і духовної культури модерного часу, не може обійти іiї увагою принаймні з двох причин: по-перше, вона засвідчує рівень української історичної думки в конфесійних середовищах на еміграції, по-друге, доносить до сучасного читача критичну інформацію про зміст і висновки низки василіянських видань, написаних чужими мовами, зокрема, латинською.

4. Щодо світської діаспорної історичної науки, то такі відомі їі представники, як Олександр Оглоблин, Омелян Пріцак, Василь Ленцик, Богдан Казимира, Юрій Гаєцький та ін. оцінювали досягнення василіянської історіографії критичніше, хоча загалом дали їм позитивну оцінку. Особливо високо оцінено доробок василіян у галузі археографії та бібліографії, хоча поза їхньою увагою не залишалися також василіянські історико-церковні дослідження.

19 Там само, с. 7.

${ }^{20}$ Шкраб’юк, П. (2005), Монаший Чин отців Василіян унаціональномужитті України: Монографія. ВВП «Місіонер», Львів, с. 268. 
5. Українська історична наука почала вивчати василіянську історіографію завдяки таким відомим вітчизняним ученим, як Василь Ульяновський, Сергій Плохій, Петро Шкраб’юк, Олексій Ясь та ін. Зазначені автори у своїх розвідках, рецензіях й окремих статтях про істориків-василіян дали позитивну оцінку науковому рівню їхніх археографічних та історико-церковних видань і в такий спосіб прислужилися до популяризації досягнень василіянської історичної науки на батьківщині.

\section{СПИСОК ЛІТЕРАТУРИ}

1. Ваврик, М. (1985), «Провідні ідеї праць о. А. Великого в його студіях української церковної історії», Записки ЧСВВ, сер. 2, сек. 2, т. 12. Рим, с. 7-84.

2. Войнар, М. (1985), «Отець Михайло Ваврик, ЧСВВ - педагог», Записки ЧСВВ, сер. 2, сек. 2. т. 12, вип. 1/4, Рим, с. 195-199.

3. Кінах, Г. (1974), «Бібліографія о. Атанасія Г. Великого, ЧСВВ - ініціатора і співробітника другої серії “Записок ЧСВВ”», Записки ЧСВВ, сер. 2, сек. 2, т. 9. Рим, c. 303-324.

4. Ленцик, В. (1985), «Отець Атанасій Г. Великий - як історик Української Церкви», Записки ЧСВВ, сер. 2, сек. 2, т. 12. Рим, с. 69-76.

5. Назарко, I. (1972). «Отець д-р Теодосій Тит Галущинський ЧСВВ», за ред. Михайла Островерхи, Бучач і Бучаччина. Історично-мемуарний збірник, НТШ, Український архів, т. XXVII. Ню Йорк, Лондон, Париж, Сидней, Торонто, с. 116-119.

6. Назарко, I., (1954), «Святий Володимир Великий - володар і хреститель РусиУкраїни (960-1015)», Записки ЧСВВ, сер. 2, сек. 1: Праці, т. IV. Рим, XXXII+228 с.

7. Назарко, I. (1962), «Київські і Галицькі митрополити. Біографічні нариси (15901960)». Записки ЧСВВ, сер. 2, сек. 1: Праці, т. XIII. Рим, XVIII+272 с.

8. Патрило, І. (1985), «Життя і творчість о. Атанасія Великого, ЧСВВ», Записки ЧСВВ, сер. 2, сек. 2, т. 12. Рим, с. 3-57.

9. Пекар, А. (1985), «Отець М. Ваврик, ЧСВВ - як історик Василіянського Чину», Записки ЧСВВ, сер. 2, сек. 2, т. 12, вип. 1/4. Рим, с. 171-187.

10. Пріцак, О. (1985), «Отець Атанасій Великий, ЧСВВ - археограф», Записки ЧСВВ, сер. 2, сек. 2, т. 12. Рим, с. 58-68.

11. Ульяновський, В. (1994), «Збирач дорогоцінного каміння: Унікальна праця отця І. Патрила», «Старожитності», № 7/8 (66/67), с. 7-8.

12. Шкраб’юк, П. (2005), Монаший Чин отиів Василіян у національному житті України: Монографія, ВВП «Місіонер», Львів, с. 259-275.

13. «Acta Innocentii IV» (1243-1254). (1962), E Regestis Vaticanis aliisque Fontibus collegerunt notisque adornarunt Theodosius T. Haluščynskyj [...]et Meletius Wojnar OSBM, Pontificia Commissio ad Redigendum Codicem Juris canonici orientalis: Fontes, Ser. III, Vol. 4, t. 1. Romae, XLIV+226 p.

14. «Acta S. Congregationis de Propaganda Fide Ecclesiam Catholicam Ucrainae et Bielarusjae spectantia», (1953), Collegit A. G. Welykyj, Analecta OSBM, ser. 2, sec. 3, vol. 1. Romae, XVI+368 p.

15. Patrylo, I. (1962), «Archiepiscopi-Metropolitani Kievo-Halicienses», Analecta OSBM, ser. 2, sec. 1: Opera, vol. XVII. Romae, XVI+142. 


\section{REFERENCES}

1. «Acta Innocentii IV»(1243-1254). (1962), E Regestis Vaticanis aliisque Fontibus collegerunt notisque adornarunt Theodosius T. Haluščynskyj [...]et Meletius Wojnar OSBM, Pontificia Commissio ad Redigendum Codicem Juris canonici orientalis: Fontes, Ser. III, Vol. 4, t. 1. Romae, XLIV+226 p.

2. «Acta S. Congregationis de Propaganda Fide Ecclesiam Catholicam Ucrainae et Bielarusjae spectantia», (1953), Collegit A. G. Welykyj, Analecta OSBM, ser. 2, sec. 3, vol. 1. Romae, XVI+368 p.

3. Kinach, H. (1974), «Bibliografiia o. Atanasiia H. Velykoho, OSBM - initsiatora i spivrobitnyka druhoii serii "Analecta OSBM"», Analecta OSBM, ser. 2, sec. 2, t. 9. Romae, p. 303-324.

4. Lentsyk, V. (1985), «Otets Atanasii Velykyi-yak istoryk Ukrainskoi Tserkvy», Analecta OSBM, ser. 2, sec. 2, t. 12. Romae, p. 69-76.

5. Nazarko, I. (1954), «Sviatyi Volodymyr Velykyi - volodar i hrestytel Rusy Ukrainy (960-1015)», Analecta OSBM, ser. 2, sec.1: Pratsi, t. IV. Romae, p. XXXII+228 c.

6. Nazarko, I. (1962), «Kyivski I Halytski mytropolyty. Biografichni narysy (1590-1960)». Analecta OSBM, ser. 2, sec.1: Pratsi, t. XIII. Romae, p. XVIII+272 c.

7. Nazarko, I. (1972). «Otets d-r Teodosii Tyt Halushchynskyi OSBM», za red. Myhaila Ostroverhy, Buchach i Buchachchyna. Istorytshno-memuarnyi zbirnyk, NTSH, Ukrainskyi arhiv, t. XXVII. New York, London, Paris, Sydney, Toronto, s. 116-119.

8. Patrylo, I. (1962), «Archiepiscopi-Metropolitani Kievo-Halicienses», Analecta OSBM, ser. 2, sec. 1: Opera, vol. XVII. Romae, XVI+142.

9. Patrylo, I. (1985), «Zhyttia i tvorchist o. Atanasiia Velykoho, OSBM», Analecta OSBM, ser. 2, sec. 2, t. 12. Romae, p. 3-57.

10. Pekar, A. (1985), «Otets M. Vavryk OSBM - yak istoryk Vasylianskoho Tchynu», Analecta OSBM, ser. 2, sec. 2, t. 12, vyp.1/4. Romae, p. 171-187

11. Pritsak, O. (1985), «Otets Atanasii Velykyi OSBM - arheograf», Analecta OSBM, ser. 2, sec. 2, t. 12. Romae, p. 58-68.

12. Vavryk, M. (1985), «Providni ideii prats o. A.Velykoho v ioho studiiach ukrainskoii tserkovnoii istorii», Analecta OSBM, ser. 2, sec. 2, t. 12. Romae, p. 7-84.

13. Voinar, M. (1985), «Otets Myhailo Vavryk, OSBM - pedahoh», Analecta OSBM, ser. 2, sec. 2, t. 12, vyp. 1/4.Romae, p. 195-199.

14. Shkrabiuk, P. (2005), Monashyi Tchyn otsiv Vasylian u natsionalnomu zhytti Ukrainy: Monografia, VVP "Misioner", Lviv, s. 259-275.

15. Ulianovskyi, V. (1994), «Zbyrach dorohotsinnoho kaminnia: Unikalna pracia otcia I. Patryla», «Starozhytnosti», № 7/8 (66/67), s. 7-8. 


\title{
THE CONTRIBUTION OF THE BASILIAN SCHOLARS INTO THE UKRAINIAN HISTORIOGRAPHYIN THE CONTEXT OF SCIENTIFIC PERIODICALS IN THE SECOND HALF OF THE XX ${ }^{\mathrm{TH}}$ CENTURY
}

\author{
Maryan Lozynskyi \\ Ivan Franko National University of Lviv, \\ Generala Chuprynky Str. 49, 79044, Lviv, Ukraine \\ e-mail:Lozmaryk@gmail.com \\ https://orcid.org/0000-0002-5006-3291
}

The publishing activity of famous writers, priests of Basilian Order of St. Basil the Great is described in the article. First of all, it's about Platonid Filyas, Soter Ortynskyi, Klym Sarnytskyi, Andrey Sheptytskiy.

The scientific and theological processes of these priests enriched the religious and national heritage of the Ukrainian state both in Ukraine and abroad. Some Basilian missionaries, including Theodosius Titus of Halushchynskyi (1880-1952) created the Basilian historiography in Galicia in the 20-30's, as well as contributed to the organization, teaching and research activities in Rome after World War II. According to the researchers, wrote on the history of the Holy Scriptures of the Old and New Testaments, on the dogmatic, moral-ascetic, philosophical issues.

Two other Basilian historians Atanazyi Hrygoriy the Great (1918-1982) and Izydor Ivan Patrylo (1919-2008) successfully combined historical and ecclesiastical aspects with special political ones.

This follows from the works published in "Annotations of Basilian Order of St. Basil the Great" by Atamazyi the Great (some 55 books) and a doctoral dissertation by Izydor Patryl "Archbishop-Metropolitan of Kyiv-Halych" published in Rome in 1962. For the first time, the legal status and power of the Kyiv-Halych Metropolitans was considered in Ukrainian church historiography. Thus, the historiography of the work by the Basilian historians is divided into two periods: diaspora and national. The study of this work by the Basilian Priests took place with the participation of the World Diaspora Historical Science, whose representatives were Oleksandr Ohloblyn, Omelyan Prittsak and others.

A concise and substantial analysis of Basilian historiography is of essential importance for a better understanding of the Ukrainian Church and the Ukrainian people.

Key words: scientific and theological works, priests, "Nyva", "Theology", "Annotations of Basilian Order of St. Basil the Great”. 